\title{
Subject Status Category
}

National Cancer Institute

\section{Source}

National Cancer Institute. Subject Status Category. NCI Thesaurus. Code C117661.

A classification of subject status data. 